\title{
Pengolahan Limbah Cair Domestik Pada PMKS PT Sisirau di Kabupaten Aceh Tamiang
}

\author{
Oppy Mandasari ${ }^{1}$, Fadhliani ${ }^{1}$, dan Vivi Mardina ${ }^{1 *}$ \\ ${ }^{1}$ Program Studi Biologi, Fakultas Teknik, Universitas Samudra \\ * Correspondence author: vmardina@ unsam.ac.id ; Tel: 082326843572 \\ Received: 25 Februari 2021; Accepted: 9 Maret 2021; Published: 10 Maret 2021
}

\begin{abstract}
Abstrak
Air buangan dari kegiatan rumah tangga atau disebut limbah cair domestik pada perumahan di sekitaran PMKS berpotensi menjadi salah satu sumber pencemaran lingkungan jika tidak dilakukan pengolahan secara benar. Penelitian ini bertujuan untuk memantau aktivitas pengolahan limbah cair domestik pada PMKS (PT Sisirau) Kabupaten Aceh Tamiang. Penelitian menggunakan metode grab sampling. Parameter pengamatan dari sampel air buangan pada perumahan pabrik adalah kadar pH, BOD, COD, TSS, ammoniak, minyak dan lemak. Data yang diperoleh dianalisa dengan membandingkan hasil yang diperoleh sesuai Permen LH dan Kehutanan RI No. P.68/Menlhk/Setjen/Kum.1/8/2016. Hasil penelitian menunjukkan bahwa limbah cair domestik di PMKS PT Sisirau sudah memenuhi standar baku mutu kualitas limbah cair yang aman di buang ke badan air yaitu nilai $\mathrm{pH}, \mathrm{BOD}, \mathrm{COD}$, TSS, ammoniak, minyak dan lemak berturut-turut adalah 8,02;23,9mg/L; 50,99mg/L;25mg/L; $0,29 \mathrm{mg} / \mathrm{L}$; dan $<2 \mathrm{mg} / \mathrm{L}$. Nilai-nilai ini berada dibawah kadar maksimum standarisasi.
\end{abstract}

Kata kunci: Limbah cair, grab sampling, Permen LH dan Kehutanan RI tahun 2016.

\section{Pendahuluan}

Limbah domestik yaitu air buangan yang berasal dari kegiatan rumah tangga, contohnya air bekas cucian, dapur, dan air dari toilet. Kandungan Limbah domestik terdiri dari 85\% protein, $25 \%$ karbohidrat, dan $10 \%$ lemak. Ada beberapa cara yang dapat dilakukan dalam pengolahan limbah cair. Salah satunya pengolahan limbah secara biologis. Pengolahan secara biologi merupakan alternatif dalam pengolahan limbah dengan menggunakan aktivitas mikroorganisme seperti mikroba ataupun tumbuhan [1].

Pengolahan air limbah domestik sudah diatur dalam persyaratan kesehatan perumahan dalam Kepmenkes No. 892 Tahun 2001. Salah satu syaratnya yaitu air limbah yang dihasilkan 
dari kegiatan rumah tangga tidak boleh mencemari sumber air, tidak menimbulkan bau atau racun yang menyebabkan pencemaran permukaan tanah. Maka dari itu, diperlukan teknik pengolahan air limbah yang tidak memiliki dampak buruk bagi lingkungan dan kesehatan makhluk hidup. Salah satu pendekatan dalam mengolah air limbah domestik adalah cara terpadu menggunakan Instalasi Pengolahan Air Limbah (IPAL) Komunal [2].

Kebutuhan pada sumber air untuk kegiatan rumah tangga, komersial, industri, dan pertanian meningkat dari tahun ke tahun. Populasi manusia akan terus bertambah jumlahnya, Hal ini juga berdampak pada penggunaan air yang terus meningkat. Disisi lain, peningkatan jumlah manusia tidak sebanding dengan persediaan air. Dari 100 negara yang disurvei oleh World Resources Institute pada tahun 1986, lebih dari setengah dinilai memiliki ketersediaan air rendah sampai sangat rendah, dan penyebab berkurangnya ketersediaan air bersih disebabkan oleh kualitas air yang menurun. Pentingnya penggunaan ulang air limbah sudah banyak dipahami oleh masyarakat, baik di negara maju maupun negara berkembang dan banyak negara sekarang mencari cara untuk meningkatkan dan memperluas pengolahan air limbah agar dapat digunakan kembali [3]. Pengolahan limbah cair untuk digunakan kembali dapat mengurangi tingkat pencemaran lingkungan yang disebabkan oleh limbah cair domestik [4]. Berdasarkan uraian sebelumnya maka penelitian ini bertujuan untuk mengetahui aktivitas pengolahan limbah cair domestik pada pengolahan limbah cair di perumahan PMKS PT Sisirau, Aceh Tamiang.

\section{Metode Penelitian}

Pelaksanaan penelitian pengolahan limbah cair domestik dilakukan di PMKS PT Sisirau, Desa Sidodadi, Kec. Kejuruan Muda, Kab. Aceh Tamiang. Sampel yang diambil pada penelitian yaitu limbah cair pada pembuangan kolam terakhir sebelum dibuang ke badan air. Secara umum tahapan penelitian yang dilakukan adalah (a) studi pendahuluan (observasi), (b) pelaksanaan, (c) pengumpulan data, (d) dan identifikasi. Observasi bertujuan untuk memperoleh informasi tentang lokasi yang akan dijadikan tempat penelitian serta pengumpulan data sekunder [5]. Pengamatan limbah dilakukan menggunakan metode eksploratif, yaitu melakukan penjelajahan di sepanjang jalur kolam limbah [6]. Pengumpulan data dilakukan dengan cara grap sampling. Jenis-jenis kolam limbah dan fungsinya dicatat. Identifikasi karaktersitik dan zat yang terkandung dalam limbah cair domestik ( $\mathrm{pH}, \mathrm{BOD}, \mathrm{COD}$, TSS, ammoniak, lemak) dilakukan pada laboratorium PMKS PT. Sisirau dengan mengacu pada metode yang disarankan Sitorus dan Mardina [7]. Data yang diperoleh dianalisa dengan 
membandingkan hasil yang diperoleh sesuai Permen LH dan Kehutanan RI No. P.68/Menlhk/Setjen/Kum.1/8/2016.

\section{Hasil penelitian}

Hasil penelitian yang diperoleh adalah karakteristrik pada limbah domestik perumahan di PT Sisirau yaitu pH, BOD, COD, TSS, $\mathrm{NH}_{3}-\mathrm{N}$. dan minyak dan lemak (Tabel 1). Selain itu terdapat kolam-kolam penampungan air limbah domestik yang diterapkan di PMKS PT Sisirau, sebelum di alirkan ke badan air. Kolam penampungan limbah domestik perumahan PT Sisirau terdiri dari:

\subsection{Kolam 1 (Anaerobic)}

Kolam anaerobik berfungsi mereduksi kandungan organik yang dibantu bakteri anaerob [7]. Kolam anaerobik dibuat dengan sistem terbuka agar dapat menerima kandungan organik yang tinggi. Zat padat yang terbawa dalam aliran air limbah akan mengendap pada dasar kolam dan kemudian diuraikan secara anaerobik oleh bakteri yang terkandung dalam air limbah, seperti bakteri saprofilik.

\subsection{Kolam 2 (Fakultatif)}

Kolam fakultatif memiliki fungsi mengolah limbah cair yang bersumber dari efluen kolam anaerobik, lapisan dasar kolam terdapat bakteri anaerobic yang berperan menguraikan zat organik, pada lapisan bagian tengah terdapat bakteri fakultatif sedangkan pada lapisan atas yang berperan adalah bakteri aerobic. Pada bagian dasar kolam fakultatif akan terbentuk asam organik dan alkohol yang terurai lebih lanjut menjadi $\mathrm{CO}_{2}+\mathrm{NH}_{3} \mathrm{H}_{2} \mathrm{~S}+\mathrm{CH}_{4}$. Pada bagian atas akan terjadi proses aerobik yang dipengaruhi oleh interaksi permukaan dan adanya bantuan sinar matahari dalam membantu proses simbiosis antara algae dan bakteri, sehingga terurainya organik dan terbentuk sel bakteri baru.

\subsection{Kolam 3 (Aerobic)}

Peran mikroorganisme sangat berpengaruh pada kolam ini yang berfungsi untuk menurunkan atau menghilangkan substrat tertentu, seperti senyawa - senyawa organik biodegradable yang terdapat dalam limbah cair. Pada kolam ini, tersedia oksigen dan ditumbuhi mikroba heterotrof seperti ganggang $[8,9]$.

\subsection{Kolam 4 (Maturasi)}

Kolam maturasi memiliki fungsi untuk menurunkan kandungan mikroorganisme dalam air limbah terutama fecal coliform, dan juga berperan dalam penurunan BOD. Menurut IPAL domestik kolam maturasi berfungsi untuk mereduksi atau menguraikan kandungan bahan 
organik secara aerobik dari effluen kolam fakultatif selama 3 hari, sehingga aman untuk dibuang ke badan air.

Tabel 1. Perbandingan Data Standarisasi Baku Mutu Limbah Domestik Dan Hasil Analisa Limbah Domestik perumahan Pabrik Kelapa sawit PMKS PT Sisirau.

\begin{tabular}{|l|l|c|c|}
\hline No & \multicolumn{1}{|c|}{ Parameter } & $\begin{array}{c}\text { Hasil Analisa Limbah } \\
\text { Domestik PMKS PT Sisirau }\end{array}$ & $\begin{array}{c}\text { Kadar Standarisasi } \\
\text { Maksimum }\end{array}$ \\
\hline 1. & pH & 8,02 & $6-9$ \\
\hline 2. & BOD & $23,9 \mathrm{mg} / \mathrm{L}$ & $30 \mathrm{mg} / \mathrm{L}$ \\
\hline 3. & COD & $50,99 \mathrm{mg} / \mathrm{L}$ & $100 \mathrm{mg} / \mathrm{L}$ \\
\hline 4. & TSS & $25 \mathrm{mg} / \mathrm{L}$ & $30 \mathrm{mg} / \mathrm{L}$ \\
\hline 5. & Ammoniak $\left(\mathrm{NH}_{3}-\mathrm{N}\right)$ & $0,29 \mathrm{mg} / \mathrm{L}$ & $10 \mathrm{mg} / \mathrm{L}$ \\
\hline 6. & Minyak dan Lemak & $<2 \mathrm{mg} / \mathrm{L}$ & $5 \mathrm{mg} / \mathrm{L}$ \\
\hline
\end{tabular}

Sumber : Permen LH dan Kehutanan RI No. P.68/Menlhk/Setjen/Kum.1/8/2016 dan Hasil Outlite limbah Domestik PMKS PT Sisirau.

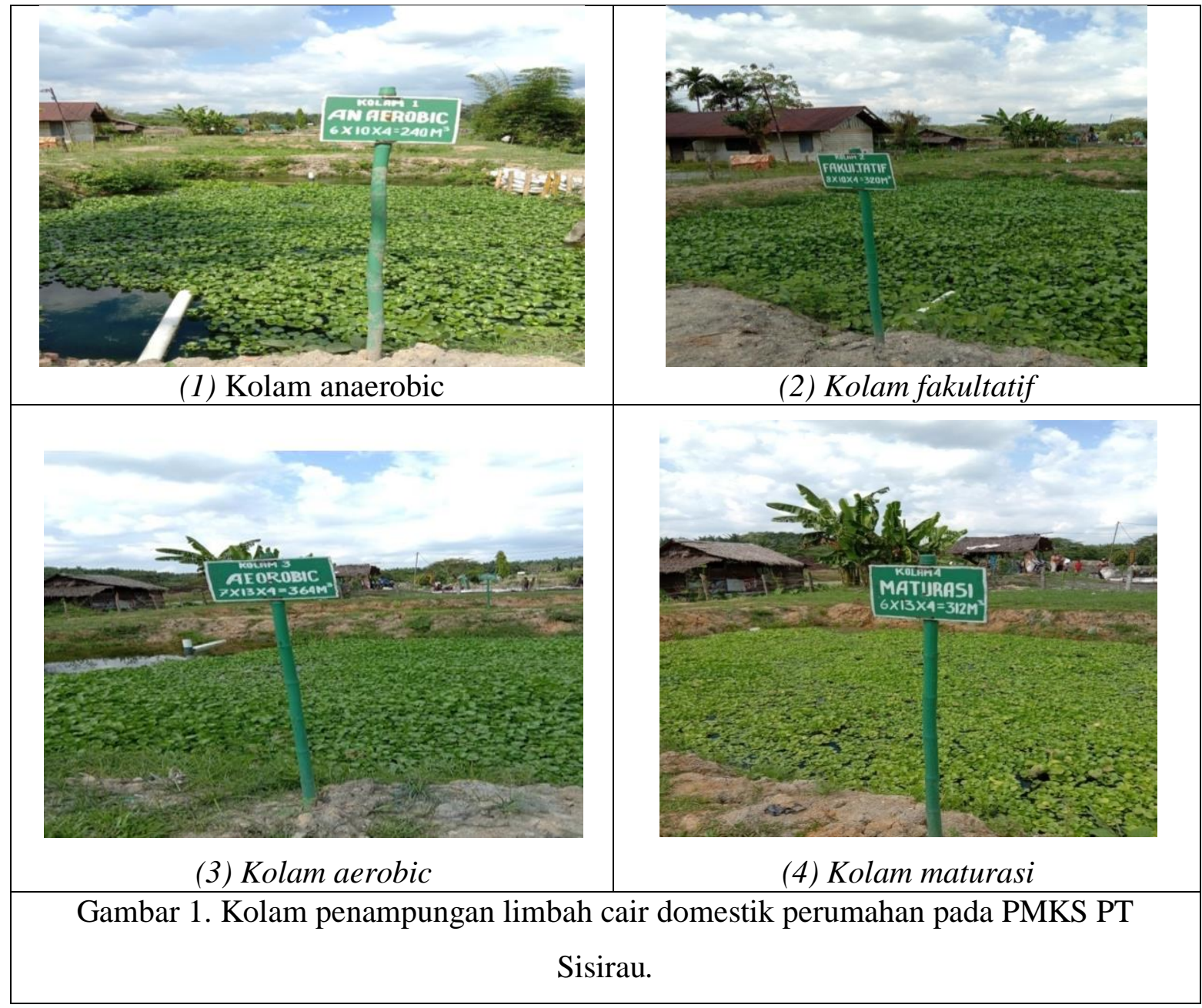




\section{Pembahasan}

Berdasarkan lampiran Permen LH dan Kehutanan RI No.P.68/Menlhk/ Setjen/Kum.1/8/2016 kadar pH masih tergolong normal yaitu 6,5 karena kadar maksimum antara 6-9. Kep. MENLH No. 51/MENLH/10/1995 menetapkan kadar standarisasi pH maksimum adalah 8,62 [9]. Nilai $\mathrm{pH}$ yang basa dapat dipengaruhi karena didalamnya terdapat zat-zat bersifat basa seperti sabun, sampo, deterjen dan sebagainya. Nilai $\mathrm{pH}$ tersebut juga dipengaruhi oleh nilai $\mathrm{pH}$ awal limbah yang berbeda-beda dalam setiap perlakuan. Ketika penambahan aerasi pada sistem dapat menyebabkan kandungan oksigen terlarut dalam air limbah meningkat. Oksigen terlarut dimanfaatkan oleh mikroorganisme untuk respirasi dan dihasilkan $\mathrm{CO}_{2}$. Karbon dioksida yang terlarut dalam air kemudian akan mengalami reaksi kesetimbangan menghasilkan ion $\mathrm{OH}$ penyebab nilai $\mathrm{pH}$ meningkat.

Biologycal Oxigen Demand (BOD) menunjukkan bahwa kandungannya telah memenuhi baku mutu air limbah domestik yaitu 23,9 mg/L dengan baku mutu $30 \mathrm{mg} / \mathrm{L}$. Tingginya kadar BOD pada efluen IPAL komunal dipengaruhi oleh banyaknya kandungan bahan-bahan organik yang masuk ke dalam sistem IPAL, yang tidak diimbangi dengan proses pengolahan air limbah yang sesuai. Selain itu debit air limbah juga mempengaruhi kemampuan IPAL dalam menurunkan BOD. Semakin besar debit air limbah maka penurunan BOD semakin menurun. Penurunan konsentrasi BOD menunjukkan bahwa bahan organik yang terkandung dalam air limbah sebagian besar merupakan bahan organik yang bersifat biodegradable (dapat terdegradasi secara biologis).

Chemical Oxygen Demand (COD) data hasil analisa yang didapatkan menunjukkan bahwa kandungan COD pada limbah domestik masih jauh di bawah ambang batas yaitu 50,99 mg/L di bandingkan dengan kadar standarisasi maksimum yaitu $100 \mathrm{mg} / \mathrm{L}$. Efisiensi penyisihan kandungan air limbah bergantung pada konsentrasi dan lamanya waktu penyimpanan di dalam sistem, waktu retensi yang cukup akan terjadi kontak antara mikroorganisme dengan air limbah. Bahan organik yang terdapat didalam air limbah akan dirombak oleh mikroorganisme menjadi senyawa lebih sederhana yang dimanfaatkan oleh tumbuhan sebagai nutrient, dan sistem perakaran tumbuhan air akan menghasilkan oksigen yang dapat digunakan sebagai sumber energi/katalis untuk rangkaian proses metabolisme bagi kehidupan mikroorganisme.

Kadar zat padat tersuspensi (TSS) masih tergolong normal yaitu $25 \mathrm{mg} / \mathrm{L}$ dengan kadar maksimum yang ditetapkan oleh Kepmen LH sebesar 30 mg/L. Penambahan oksigen ke dalam limbah cair berfungsi menghancurkan endapan-endapan yang tergumpal sehingga akan 
mempermudah penyerapan oksigen. Semakin banyak bakteri pengurai yang dapat menguraikan endapan-endapan yang tergumpal maka nilai TSS juga menjadi turun.

Kadar ammoniak adalah 0,29 mg/L juga masih jauh dari ambang batas baku mutu yaitu $10 \mathrm{mg} / \mathrm{L}$. Kemampuan IPAL dalam menurunkan amonia dipengaruhi antara lain oleh debit aliran limbah dan waktu tinggal. Semakin besar debit air limbah yang masuk kedalam sistem pengolahan IPAL maka akan semakin kecil penurunan kadar amonia, sedangkan semakin lama waktu tinggal maka efektifitas penurunan amonia semakin tinggi. Kandungan amonia didalam air limbah domestik dapat turun setelah melalui pengolahan pada kompartemen IPAL amonia dalam air limbah menjadi nitrit atau nitrat melalui reaksi nitrifikasiyang dibantu oleh aktivitas mikroorganisme

Kandungan minyak dan lemak. Dari hasil analisa yang diperoleh menunjukkan bahwa kandungan minyak dan lemak telah memenuhi baku mutu air limbah domestik yaitu $2 \mathrm{mg} / \mathrm{L}$ dan tidak melewati ambang batas yaitu $5 \mathrm{mg} / \mathrm{L}$. Penyebab nilai minyak dan lemak rendah pada limbah dikarenakan air limbah yang digunakan dalam penelitian ini diambil dari efluen bak sedimentasi, sehingga sebagian besar kandungan minyak dan lemak telah berkurang [10].

Peningkatan efisiensi penyisihan bahan organik sejalan dengan peningkatan waktu hidraulik, hasil ini disebabkan karena semakin panjang waktu kontak antara bahan organik dengan bakteri di biofilm, semakin banyak juga kesempatan bakteri untuk mempergunakan bahan organik untuk metabolis tubuhnya [11].

\section{Kesimpulan}

Penelitian ini menyimpulkan bahwa

a. Pengolahan limbah domestik yang ada diperumahan pabrik kelapa sawit PMKS P.T Sisirau menggunakan sistem kolam yang tersusun mulai dari kolam anaerobik, kolam fakultatif, kolam aerobik, dan terakhir kolam kolam maturasi.

b. Karakteristik kimia pada limbah domestik yang meliputi pH, BOD, COD, TSS, ammoniak, minyak dan lemak sudah memenuhi baku mutu nasional sesuai dengan Permen LH dan Kehutanan RI No. P.68/Menlhk/Setjen/Kum.1/8/2016 karena hasil yang didapatkan masih dibawah ambang batas yang ditetapkan.

Acknowledgments: penulis berterimakasih kepada Bapak Sahri Agustiar S.T yang sudah membimbing saat melakukan penelitian di PMKS P.T Sisirau

Conflicts of Interest: The authors declare no conflict of interest 


\section{Daftar pustaka}

1. Indriyati, 2007. Unjuk Kerja Reaktor Anaerob Lekat Diam Terendam dengan Media Penyangga Potongan Bambu. Pusat Teknologi Lingkungan Badan Pengkajian dan Penerapan.

2. Kementerian ESDM RI. 2001. Peraturan Pemerintah RI No. 82 Tahun 2001 tentang Pengelolaan Kualitas Air dan Pengendalian Pencemaran Air. Diakses dari http://www.minerba.esdm.go.id/library/sijh/ PP8201_KualitasAir.pdf.

3. Vigneswaran, S. dan M. Sundaravadivel. 2004. Recycle and Reuse of Domestic Wastewater in Wastewater Recycle, Reuse, and Reclamation. Encyclopedia of Life Support System.

4. Arsawan, M. Suyasa.I.W.B, dan Suarna, W. 2007. Pemanfaatan Metode Aerasi dalam Pengolahan Limbah Minyak. Ecotrophic 2(2):1-9

5. Sugiarto. 2016. Dasar-Dasar Pengelolaan Air Limbah. Jakarta: UI Press.

6. Octavianus, Dody. 2013. Pengolahan Limbah Domestik dengan menggunakan Biokoagulan Biji Moringa oleifera Lam. dan Saringan Pasir Cepat. Jurnal Reka Lingkungan Itenas, $1(2)$.

7. Sitorus Y.R dan Mardina, V. 2020. Karakteristik kimia dari pengolahan limbah cair kelapa sawit PTPN Y. Jurnal Enviroment Science, 4 (2): 58 - 66.

8. Surbakti, B.J., Mardina V, Fadhliani. 2020. Karakteristik limbah cair hasil pengolahan sistem lumpur aktif pada pabrik kelapa sawit PTPN II Tanjung Morawa, Kebun Sawit Seberang

9. Yuna, R dan Mardina V. 2019. Pengujian Karakteristik Kimia pada Limbah Cair Kelapa Sawit di Pabrik X. Jurnal Biologica Samudra, 1 (1): 1 - 8. Jurnal Biologica Samudra, 2 (2): $95-102$.

10. Hendrawan, Diana. 2008. Kualitas air sungai Ciliwung ditinjau dari parameter minyak dan lemak. Jurnal Ilmu-ilmu Perairan dan Perikanan Indonesia, 15(2), 85-93.

11. Metcalf dan Eddy, inc. 2003. Watewater Engineering: Treatment Disposal and Reuse. McGraw-Hill, inc:USA. 